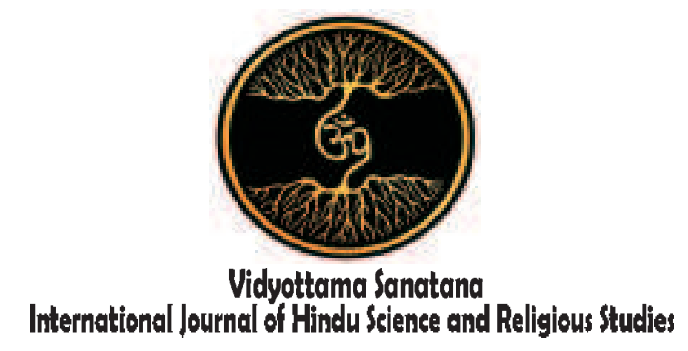

Vol. 1 No. 2 October 2017

\title{
Understanding Buddhism Through Pali in India and Thailand
}

\author{
By: \\ Upender Rao \\ Special Centre for Sanskrit Studies, \\ Jawaharlal Nehru University, \\ New Delhi 110067, India \\ \begin{tabular}{|l|l|l|}
\hline Received: July 20, 2017 & Accepted: October 15, 2017 & Published: October 30, 2017 \\
\hline
\end{tabular}
}

\begin{abstract}
Pali plays a vital role in the history and culture of India. It preserves the Indian culture in a systematic way. Hence an attempt of understanding the Indian culture without Pali cannot fulfil the complete purpose. In fact Pali was an important source for understanding ancient Buddhist culture and philosophy which are integral part of Indian culture. In ancient India there were Buddhist universities and people from many countries used to visit India to learn the Indian culture including Buddhist philosophical expositions. Indian languages and literatures were highly influenced by Pali language and literature.
\end{abstract}

Key Words: Buddhism, Pali, India and Thailand

\section{Introduction}

When we consider a comparative perspective of religion and social change we have to look at the Buddhism and its development, its literature and its role in everyday life in India and Thailand. This paper focuses on Buddhism and its education through teaching of Pali. It aims mainly to focus on comparative and collaborative issues between Thailand and India.

Pali is an important language for understanding Buddhism both in India and
Thailand. Entire canonical early Buddhist literature is available in Pali language. Teachers of Mahâyâna Buddhism in later period adopted Sanskrit for their various Buddhist philosophical and logical writings and for other Buddhist expositions. Yet Pâli remains virtually the actual basis for understanding the Buddhism and its basic tenets.

Lord Buddha's marvellous words are preserved in Pâli,

Sabbe tassanti dan

assa sabbe bhâyanti maccuno / 
AttânaA upamaA kattvâ na haneyya na ghâtaye "” I

Sabbe tassanti dan

assa sabbesam jîvitaA piyaA/

AttânaA upamaA katvâ na haneyya na ghâtaye//2

na hi verena verâni sammantîdha

kudâcanaA/

avereGa ca sammanti esa dhammo sanantano// ${ }^{3}$

These verses are from 'Dhammapada' ${ }^{4}$. The text Dhammapada is an anthology of 423 verses, which has been recognized as one of the masterpiece of early Buddhist Literature and which is most popular canonical text in both India and Thailand. It can be considered as quintessence of tripimaka literature.

'Dhammapada' was composed in Pali language. thus not only for Buddhist philosophy and literature, being one of most ancient language of India, Pali can occupy a prominent place in the history of India. Through Buddhist literature Pâli reveals us the most important incidents which had occurred in India during Buddha's period and even later period. Thus this literature presents us the Indian history from $6^{\text {th }}$ century B. C. to $6^{\text {th }}$ Century A. C. i.e. the history of India which took place roughly for 1200 years.

Not only Indian history, Buddha's unparalleled teachings are preserved in Pali. Today we can find some people showing a lot of curiosity on Buddhism. They also speak about Buddhism without the knowledge of Pali. But we have to consider that one cannot get the real understanding of Buddha's teachings without the awareness of Pali language. Undoubtedly some Indian scholars have done some good researches on Pali but yet there are several areas which need to be explored even today.

\section{Results And Discussion}

\subsection{Linguistic relation between Pali and Indian languages:}

Pali can be considered a kind of Prakrit language. We should understand that Prakrit was not a single language. It is rather better to call it a group of the widely spoken languages in Jambûdvîpa. Therefore we have so much affinity between the chandas and the Prakrit which includes Pâli as well. But at the same time we cannot ignore the importance of Sanskrit language and its enormous contribution to India and to entire world. But we should consider Pali, which being sisterly language of Sanskrit, shares the motherhood to its children of Indian languages. Pali which belongs to the middle Indo Aryan period is one of the prominent ancient languages. 'Mâgadhi' was the original name of Pali as it was the spoken in the land of Magadha during the 6th century B. C., the period in which lord Buddha has lived and preached his great message of compassion and dependent origination theory and many more invaluable teachings.

The antique Pali Literature reveals India's philosophical, social and religious condition in a most authentic manner. ${ }^{5}$ Some middle IndoAryan languages became important vehicles; the best known among them is Pali, which still serves as the canonical language of Buddhism in Thailand, Sri Lanka and other Southeast Asian countries. Other Prâkrit languages such as Úaurasenî, Mahârâcmrî, Mâgadhî, and

\footnotetext{
${ }^{1}$ Dhammapada/129

${ }^{2} \mathrm{Ibid} / 130$

${ }^{3} \mathrm{Ibid} / 5$

${ }^{4}$ Dhammpada is one of the texts of 'Khuddaka Nikâya' of the Suttapimaka. 'Khuddaka Nikâya' is one of the five nikâyas of Suttapimka of Tripimka literature.

${ }^{5}$ Pali Sâhitya kâ itihâs, 1.1
} 
Gândhârî embody various facets of the literatures of both the Hindu and Buddhist traditions. The famous scholar Dan in praised Mahârâcmî Prakrit ${ }^{6}$ Indian languages and literatures were highly influenced by Pali. The words of Pâli can be found in almost in every Indian language. ${ }^{7}$ Not only Indian languages, it has influenced Thai languages and literature in Thailand. It shows how important role it played in India and Thailand. Thus through Pali we can once again re-unite with Thailand linguistically, historically and religiously.

The reason why Pali could influence both Indian and Thai languages is it is not fully comprised to grammar like Sanskrit and it is a highly inflected language, in which almost every word contains, besides the root conveying the basic meaning, one or more affixes (usually suffixes) which modify the meaning in some way. Nouns are inflected for gender, number, and case; verbal inflections convey information about person, number, tense and mood. Pâli nouns inflect for three grammatical genders (masculine, feminine, neuter) and two numbers (singular, and plural). The nouns also in principle display eight cases: ${ }^{8}$

nominative case, (pamamâ)
vocative case, $($ alapana)
accusative case, $($ dutîyâ $)$
instrumental case, $($ tatîyâ)
dative case, $($ catutthî)
ablative case, $($ paAcamî)
genitive case, $($ chammhî)
locative case $(\text { sattamî })^{9}$

However, in many instances, two or more of these cases are identical in form; this is especially true of the genitive and dative cases.
Many assimilations of one consonant to a neighboring consonant occurred in the development of Pâli, producing a large number of geminate (double) consonants. Since aspiration of a geminate consonant is only phonetically detectable on the last consonant of a cluster, geminate $\mathrm{kh}, \mathrm{gh}, \mathrm{ch}, \mathrm{jh}$, th, dh, th, $\mathrm{dh}$, ph and bh appear as kkh, ggh, cch, jjh, tth, ddh, tth, ddh, pph and bbh, not as khkh, ghgh etc. ${ }^{10}$ When assimilation would produce a geminate consonant at the beginning of a word, the initial geminate is simplified to a single consonant, Examples:

$$
\begin{aligned}
& \text { prâna } \rightarrow \text { pâna. Sthavira } \rightarrow \text { thera (not } \\
& \text { tthera), } \\
& \text { dhyâna } \rightarrow \text { jhâna (not jjhâna), jñâti } \rightarrow \\
& \text { ñâti (not ññâti). }
\end{aligned}
$$

In total assimilation one sound becomes identical to a neighbouring sound. This is of two types: progressive, where the assimilated sound becomes identical to the following sound; and regressive, where it becomes identical to the preceding sound.

Progressive assimilations: Internal visarga assimilates to a following voiceless stop or sibilant, Examples:

$$
\begin{aligned}
& \text { duhkhta } \rightarrow \text { dukkata, } \\
& \text { duhkha } \rightarrow \text { dukkha, } \\
& \text { dusprajña } \rightarrow \text { duppañ̃na, } \\
& \text { niskrodha } \rightarrow \text { nikkodha, } \\
& \text { nispakva } \rightarrow \text { nippakka, } \\
& \text { niseoka } \rightarrow \text { nissoka, } \\
& \text { nissattva } \rightarrow \text { nissatta }{ }^{11}
\end{aligned}
$$

In a sequence of two dissimilar Sanskrit stops, the first stop assimilates to the second stop, Examples:

\footnotetext{
${ }^{6}$ mahâractrâúrayâA bhâúâA prak[cmaA prâk[taA vidu\%- Kavyâdarœa\% 1.34 as quoted in Pâlî sâhityam loni Dîghanikâyam lo tâttvika dhoraGulu, 1.25

${ }^{7}$ Telugulo Pali Padâlu, 1-6

${ }^{8}$ Pali vyâkaraGa, 2.4

${ }^{9}$ Pâli-mahâvyâkaraGa I p. no.2

${ }^{10}$ Pâli-praveúikâ 1.1

${ }^{11}$ Ibid 1.11
} 


$$
\begin{aligned}
& \text { vimukti } \rightarrow \text { vimutti, } \\
& \text { dugdha } \rightarrow \text { duddha, } \\
& \text { utpâda } \rightarrow \text { uppâda, } \\
& \text { pudgala } \rightarrow \text { puggala, } \\
& \text { udghosa } \rightarrow \text { ugghosa, } \\
& \text { adbhuta } \rightarrow \text { abbhuta, } \\
& \text { cabda } \rightarrow \text { sadda }
\end{aligned}
$$

In a sequence of two dissimilar nasals, the first nasal assimilates to the second nasal, Example:

unmatta $\rightarrow$ ummatta,

pradyumna $\rightarrow$ pajjunna.

$\mathrm{J}$ assimilates to a following $\tilde{\mathrm{n}}$ (i.e., $\mathrm{j} \tilde{n}$ becomes ñ̃̃), Examples:

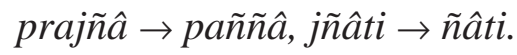

The Sanskrit liquid consonants $r$ and 1 assimilate to a following stop, nasal, sibilant, or v, Examples:

$$
\begin{aligned}
& \text { mârga } \rightarrow \text { magga, } \\
& \text { karma } \rightarrow \text { kamma, } \\
& \text { varsa } \rightarrow \text { vassa, } \\
& \text { kalpa } \rightarrow \text { kappa, } \\
& \text { sarva } \rightarrow \text { savva } \rightarrow \text { sabba }^{12}
\end{aligned}
$$

r assimilates to a following 1, Examples:

durlabha $\rightarrow$ dullabha,

nirlopa $\rightarrow$ nillopa.

$\mathrm{d}$ sometimes assimilates to a following $\mathrm{v}$, producing $\mathrm{vv} \rightarrow \mathrm{bb}$, Examples:

udvigna $\rightarrow$ uvvigga $\rightarrow$ ubbigga,

dvâdaúa $\rightarrow$ bârasa (beside dvâdasa)

$\mathrm{t}$ and $\mathrm{d}$ may assimilate to a following $\mathrm{s}$ or $\mathrm{y}$ when a morpheme boundary intervenes Examples:

ut+sava $\rightarrow$ ussava,

ud+yâna $\rightarrow$ uyyâna.

These are some of the assimilations which we usually encounter in Pali language.

\subsection{Pali Studies in Thailand:}

After the third Buddhist Council in India, Bhikkhus Sona and Uttara with their missionary group came to SuvarGa-bhûmi region to introduce Buddhism. Though in intial days it was not understood by the people living there, but in course of period they understood the importance of Buddha's unparalleled teachings and their utility in day to day life. Slowly Buddhism has become the religion of the people in this region. Buddhism was introduced into Thailand through three channels from India by land and by two routs of sea.

By land, i.e. walking through Bengal-Burma--Thailand

By sea, i.e. ship sailing through Bengal-Mataban--Davai--Tanaosi--Thailand and

By sea, i.e. ship sailing through Malacca Pass--Malayu Peninsula--Jampa-Thailand.

In the beginning, the Buddhist literary works were introduced into Thailand through these channels. But there is no any record that through which form these works entered in Thailand as to whether as manuscripts or as inscriptions. It can be inferred that the Buddhist canon and other Indian wisdom might have entered in Thailand through the oral tradition as because the oral tradition was prevailed in India during that time. Vedas, the most ancient literature in India, were preserved through the oral tradition only for several centuries and hence they are named œ[ti. In later period it was used as a name of Veda. Even Tripimaka literature was preserved in India for several centuries through this oral tradition only.

By that time there were many Buddhist philosophical and literary works authored and taught in India, especially in the period of Nâlandâ Mahâvihâra. 'Milindapañho', (The Questions of King Menander) was introduced into Thailand. Pali had already entered into Sri Lanka from India and hence the other Buddhist works entered in Tailand from Sri Lanka. In course of time Thai monks concentrated on Pali

${ }^{12}$ Ibid 1.13 
and achieved scholarship in it. Fifty-two commentaries, such as the commentary on the Vinaya Pimaka entitled 'Samanta-pâsâdikâ', the commentary on the 'Dîghanikâya'entitled 'Sumangalavilâsinî, and the commentary of 'DhammasangaGi' named Ammhasâlinî have been well known to Thai monks and laymen who are interested in Pali studies.

Not only commentary texts, other Buddhist scriptures like 'NettipakaraGa', 'Pemakopadesa', 'Visuddhimagga', 'Vimuttimagga', 'Abhidhammâvatâra', 'DîpavaAsa', 'MahâvaAsa', 'Saddanîti-ppakaraGa' 'Dhâtumâlâ-Suttamâlâ-Padamâlâ which are also well known to Thai monks and laymen.

\subsection{Pali Studies of the Thai Saàgha in the Present Day Thailand:}

The religious education of Thai Sangha in the field of Pali Studies is divided into nine grades and the text-books for each grade are fixed.

In Bangkok, there are 80 authorized religious schools of Pali, while in rural area there are 108 authorized religious schools of Pali in various provinces. However there are many more other schools throughout the country. No wonder the religious schools of Pali receive financial support mostly from lay Buddhist devotees, from senior monks and from government as well.

The process of Assessment and Evaluation is called Royal Pali Examination, because in ancient time, the Thai Kings carried on the activity involving Pali Studies by themselves. The Pali Studies examination of the Thai SaAgha is generally regarded as very difficult, as many monks and nuns fail in examination every year.

The noteworthy point is that to finish the Pali IX (Grade IX) is very difficult. It is a nineyear curriculum but actually some monks spent even 20 years to complete it. ${ }^{13}$

\footnotetext{
${ }^{13}$ web source: http://atbu.org/node/23

${ }^{14}$ website: http://mcuaad.mcu.ac.th
}

Pali Studies in Mahâ-chulalongkorn-râjavidyâlaya University:

Mahâ chulalongkorn-râja-vidyâlaya University (MCU) is a public autonomous university, like the University of the Thai SaAgha. MCU pays very much attention to Pali Studies. The MCU curriculum involving Pali Studies is as follows:

Programmes of Pali:

(1) Certificate in Pali

(2) Bachelor of Arts in Pali

(3) Bachelor of Arts in Pali Buddhist Studies

(4) Master of Arts in Pali

(B) Pali Subjects in various curriculums:

(1) In Bachelor of Arts, there are Pali subjects or related subjects in the group of CoreBuddhist Subjects of every curriculum i.e. Pâli Translation, Tipimaka Studies, Vinaya Pimaka, Suttanta Pimaka, Abhidhamma Pimaka. All the students of MCU in every major have to study these subjects.

(2) The lay students in Master Degree who have not studied Pali subjects or related subjects have to study the additional Pâli subject I and II.

(3) Pali Language is selected as one of five foreign languages which the Ph.D. students can select for qualifying examination.

(4) Scriptures and Books for Pali Studies In the present day, Mahâ-chulalongkornrâja-vidyâlaya-University (MCU) carries out many projects of producing the scriptures and books to promote Pali Studies in Thailand. ${ }^{14}$

There are many areas in which both Thai and Indian scholars can work together. I tried to figure out some areas as follows.

1. Influence of Pâli language on Indian and Thai languages.

2. Indo-Thai relations with special reference to Pâli studies. 
3. Pâli and Thai: language and literature

4. Indian history in Pâli literature and its influence on Thai literature.

5. India-Thai religious studies with reference to Pali literature

6. Poetic study of Pali canonical literature

7. Translations of Pali non canonical literature in to Thai.

8. Scientific thought in Pali literature.

9. Ethics in Pali literature and their influence on Thai literature.

10. Philosophical views in Pali literature.

11. Buddhist literature of Tahiland.

12. Ancient Indian economics in Pali literature

13. Folk lore in Pali literature and its influence onn Thai folk traditions.

14. Pali and Sanskrit: their historic and linguistic relations with Tahi.

15. Pali and Prakrit: similaries and their influence on Thai and Hindi

16. Pali language and literature in Theravada countries (Sri Lanka, Burma, Thailand etc)

17. Fine arts in Thai and Pali literatures.

18. Pali grammar and its influence on south Asian languages.

19. Pali Vamsa literature: historical perspective.

20. Pali inscriptions in India and Thailand.

21. Dictionaries in Pali: present status and future needs.

22. Pali studies in Thai and west

23. Pali translations: east and west

24. Poetics in Pali literature

25. A comparative study of Sanskrit and Pali Grammars

26. Polity in Pali literature

For Pâli chanting in Thailand one can get some material from internet sources. The following links may help the scholars in this regard.

https://www.youtube.com/

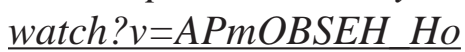

https://www.youtube.com/ watch? $v=S s B 3-t O A B H g$

https://www.youtube.com/ watch? $v=j G H D p g B c 9 D k$
Thus though basically originated in India, Pali had entered in entire world but especially in South EastAsia and influenced the languages and literatures of these countries. Pali has enriched the language and literature of Thailand as well where the tradition Pali is still kept alive. But it is noteworthy that India being its source has been contributing for Pali and maintaining its major role in the spread of Pali language. Many branches of Pali literature such as grammar, prosody and poetics follow the tradition of Sanskrit literature. Most of the rules and procedures are taken from Sanskrit tradition. Therefore if one is conversant in Sanskrit, the learning of Pali will not be difficult for him. Linguistically Pali and Sanskrit have a notable similarity.

In India we have good number of Sanskrit scholars and many of them have also studied Pali. Therefore there is a plenty of opportunity for the proper growth of Pali, provided the Thai institutions and scholars maintain a healthy academic cooperation with Indian institutions where Pali is being taught. Likewise Indian scholars and institutions also will be benefited by the knowledge of Pali scholars and institutions of Thailand as they kept the Pali tradition without interruption.

\section{Conclusion}

Thus through the mutual understandings and partner-ship India and Thailand can benefit with the abundant wisdom of Pali languages and literature. His Holiness the Dalai Lama always praises the Nâlandâ tradition where Pali was taught mainly. The Tibetan Buddhist monks and other scholars have derived a great deal of scholarship and spiritual encouragement from the Nâlandâ. Because though Buddhism has widely spread today showing a spiritual path to many and encouraging them enormously in many parts of the word with its manifold literature, Pali being its source always stands as a great inspiration to Buddhism and Buddhist scholars. 
Therefore developing Pali today removes manifold hurdles in the field of spirituality through the sustainable growth of Buddhism and this can be achieved through the Indo-Thai educational cooperation based on the Pali.

\section{References}

Dhammapada, Edited \& Translated by Dwarikadas Shastri. Varanasi: Bauddha Bharati, 2002.

Pali Sâhitya kâ itihâs, K. C. Jain, vishvavidyâlaya Prakâuan, VârâGasî,1987

Pâli-mahâvyâkaraGa, Bhikcu Jagadîua Kâúyap, Motilal Banarsi das, 1985

Pâli-praveúikâ 1.1, K. C. Jain, Târâ publication, VârâGasî,1973

Pali vyâkaraGa, Bhikcu Dharmarakcita, Jñânamanal limited, VarâGasî, vikrama samvat 2065

Beyond religion, ethics for a whole world, Harper Collins publishers india, 2012

Pâlî sâhityam loni Dîghanikâyam lo tâttvika dhoraGulu, Dr. C. U. Rao, AGvecaGa publications, Hyderabad 1997
Pali Primer, Lily de Silva, Vipassana Research Institute, Igatpuri, 2012

Telugulo Pali Padâlu, collected by Cîmakurti Úecagiri Rao, Telugu Gocmhi, Hyderabad, 1990

Dîghanikâya. Edited \& Translated by Dwarikadas Shastri. Varanasi: Bauddha Bharati, 2006.

Sammôhavinôdanî of Buddhagosa. Igatpuri : Vipassana Research Institute, 1998.

SumaEgalavilâsinî of Buddhagosa. Edited by T.W. Rhys Davids, J. Estalin Carpenter. London: Pali Texts Society, 1886.

Suttanipâta. Edited \& Translated by Dwarikadas Shastri. Varanasi: Bauddha Bharati, 2005.

Thçragâthâ. Edited \& Translated by Vimalkirti. New Delhi: Samyak Prakashan, 2008.

Narsu, P.Lakshmi, The Essence of Buddhism. Madras: Srinivasa Varadachari \& co., 1907.

Web source: http://atbu.org/node/23

Web source: http://mcuaad.mcu.ac.th 